\title{
PROSES BERPIKIR SISWA DALAM MENYELESAIKAN SOAL PEMECAHAN MASALAH BERDASARKAN GAYA BELAJAR AUDITORI
}

\author{
Siska Adi Wiguna 1), Mohamad Gilar Jatisunda 2), Erik Santoso ${ }^{3)}$, \\ ${ }^{1}$ Universitas Majalengka, 2) Universitas Majalengka, 3) Universitas Majalengka \\ email korespondensi: siskaadiwiguna11@gmail.com
}

\begin{abstract}
Penelitian ini dilaksanakan berdasarkan perbedaan setiap siswa dalam proses penerimaan informasi pelajaran berdasarkan gaya belajar dari masing-masing siswa. Fokus pada penelitian ini adalah menganalisis proses berpikir siswa dalam menyelesaikan soal-soal pemecahan masalah berdasarakan gaya belajar auditori. Penelitian ini menggunakan penelitian deskriptif kualitatif. Instrumen pada penelitian adalah rubrik gaya belajar berdasarkan teori Fleming kemudian untuk kemampuan pemecahan masalah matematis didapatkan dari instrumen soal pemecahan masalah matematis berdasarkan pemecahan masalah polya.Hasil penelitian yang didapatkan bahwa siswa dengan gaya belajar auditori memiliki kemampuan proses berpikir konseptual dengan mampu memahami masalah, mampu merencanakan pemecahan masalah, mampu melaksanakan pemecahan masalah dan mampu memeriksa kembali jawaban dengan baik.
\end{abstract}

Kata Kunci: Proses Berpikir, Pemecahan Masalah, Gaya Belajar Auditori 


\section{PENDAHULUAN}

Kemampuan untuk berpikir yang dimiliki setiap individu berbeda-beda. Sebagai contoh, dalam kehiduan seharihari, kita dihadapkan berbagai pilihan, dari mulai menu sarapan, kendaraan yang akan digunakan untuk pergi ke kantor, rute yang akan digunakan, hingga rencana untuk pulang itu berbeda. Perbedaan itu terjadi karena faktor dari kemampuan kognitif dan pengaruh dari lingkungan, NCERT (2015: 150) Thinking is the base of all cognitif activities or process and is unique to human beings. It involed manipulation and analysis of information received from the environment.

Pada proses berpikir yang terjadi pada siswa, stimulus akan menjadi informasi baginya ketika tepat dengan kemampuan respon yang dimiliki siswa, karena kemampuan berpikir siswa itu memiliki keunikan antara satu dan lainnya. Jika stimulus dapat direspon dengan baik oleh siswa, maka itu akan menjadi sebuah informasi, Nyayu Khodijah (2014: 112) Setiap Informasi yang diperoleh akan disimpan dalam long-term memory.

Jika informasi sudah tersimpan maka ketika siswa tersebut menghadapi sebuah masalah, informasi itu secara sistematis dikonstruksikan kembali oleh otak untuk memecahkan permasalahan yang dihadapi tersebut. Widyastuti (2013: 5) Dalam pemecahan masalah matematika, tidak hanya kemampuan untuk menyelesaikan masalah saja yang diperlukan oleh siswa, tetapi juga diperlukan proses berpikir yang baik.

Proses berpikir siswa dalam menyelesaikan permasalahan memiliki beberapa langkah proses berpikir. Zuhri (Milda Retna, Lailatul Mubarokah \& Suhartatik, 2013) mengungkapkan bahwa proses berpikir dibedakan menjadi tiga macam yakni

Copyright (2019, Jurnal Didactical Mathematics p-ISSN: 2622-7525, e-ISSN: 2654-9417 proses berpikir konseptual, proses berpikir semikonseptual, dan proses berpikir komputasional. Setiap proses dibedakan menjadi mampu (konseptual), kurang mampu (semikonseptual) dan tidak mampu (komputasional). Ketika dalam menyelesaikan masalah siswa mampu menggunakan konsep, maka siswa dikatakan memiliki kemampuan konseptual dalam proses berpikirnya. Ketika siswa kurang mampu menggunakan konsep, maka kemampuan proses berpikirnya adalah semi-konseptual. Dan ketika siswa tidak mampu menggunakan konsep, maka proses berpikirnya adalah komputasional.

Teori belajar kognitif merupakan suatu teori belajar yang lebih mementingkan proses belajar daripada hasil belajar (Sutarto, 2017: 2). Karena pada dasarnya belajar adalah sebuah proses pemahaman dari informasi yang didapatkan, sejauhmana pemahaman didapatkan dan itu akan menjadi kemampuan dasarnya. Kemampuan dasar ini yang kemudian dijadikan siswa sebagai amunisi memecahkan masalah yang ditemukan dalam belajar. Proses berpikir pada siswa dalam memecahkan masalah dimulai dari siswa memahami masalah hingga siswa mampu memecahkan masalahnya sendiri. Ketika proses itu terjadi seringkali mental siswa dalam menghadapi kesulitan menghambatnya untuk menyelesaikan masalah, dan tidak semua siswa mampu melewati kesulitan tersebut. Salah satu faktor yang menjadikan siswa mampu menghadapi kesulitan dalam memecahkan masalah adalah dari faktor gaya belajarnya sebagai referensi solusi yang dapat digunakan, dan seorang individu memiliki pendekatan yang berbeda untuk melakukan pendekatan terhadap masalah yang dihadapi, Carmo dkk (2006: 7) People 
learn in several ways and have different preferences when approaching new materials.

Dengan memahami gaya belajar setiap siswa, maka guru maupun siswa dapat mempermudah proses belajar mengajar didalam kelas, Due to the different preferences in the way people perceive and process information, learning styles are a useful instrument to help students and teachers understand how to improve the way they learn and teach (Carmo dkk, 2006: 7). Sehingga kemampuan dan potensi pemecahan masalahnya dapat dikembangkan dengan optimal.

Gaya belajar siswa yang akan diteliti pada penelitian ini adalah gaya belajar auditori, dimana siswa yang memiliki gaya belajar auditori adalah siswa yang memiliki kecenderungan belajar menggunakan indera pendenganrannya. Seorang peserta didik yang memiliki kemampuan auditoris sangat mungkin memiliki ciriciri sebagai berikut: 1) perhatiannya mudah terpecah, 2) berbicara dengan pola berirama, 3) belajar dengan mendengarkan, dan 4) berdialog secara internal dan eksternal (Huda, 2017:288). Dari ketiga gaya belajar dengan preferensi sensori yaitu visual, auditori dan kinestetik, penelitian ini lebih memilih meneliti kemampuan pemecahan masalah siswa auditori. Dengan kemampuan pendengarannya siswa auditori akan dilihat sejauhmana kemampuannya dalam memecahkan masalah dengan memaksimalkan potensi yang dimiliknya.

Berdasarkan uraian yang dijelaskan, tujuan dari penelitian adalah untuk menganalisis proses berpikir siswa dalam menyelesaikan soal pemecahan masalah di lihat dari gaya belajar auditori dengan segala potensi yang dimilikinya.

\section{KAJIAN LITERATUR DAN PEGEMBANGAN HIPOTESIS (JIKA ADA)}

Bagian ini berisi kajian literatur yang dijadikan sebagai penunjang konsep penelitian. Kajian literature tidak terbatas pada teori saja, tetapi juga bukti-bukti empiris. Hipotesis peneltiian (jika ada) harus dibangun dari konsep teori dan didukung oleh kajian empiris (penelitian sebelumnya). [Book Antiqua, 11, normal].

\section{METODE PENELITIAN}

Metode dalam penelitian ini adalah penelitian kualitatif deskritif, penelitian yang dimaksud untuk memahami fenomena tentang apa yang dialami oleh subjek penelitian misalnya prilaku, persepsi, motivasi, tindakan dan lain-lain secara holistik dan dengan cara deskrpsi dalam bentuk kata-kata dan bahasa, pada suatu konteks khusus yang alamiah dan dengan memanfaatkan berbagai metode ilmiah (Moleong, 2011 : 6). Peneliti akan terjun ke lapangan sendiri, baik pada grand tour question, tahapan focused and selection, melakukan pengumpulan data, analisis dan membuat kesimpulan (Sugiyono, 2016 : 223). Dalam penelitian kualitatif instrumen utamanya adalah peneliti sendiri, pengambilan data dilakukan dengan menganalis jawaban-jawaban soal siswa melalui tes soal kemampuan pemecahan masalah matematis kemudian untuk memperdalam kajian di lakukan wawancara . Penelitian ini dilaksanakan di MA Siti Khadijah Kec. Sindangwangi Kabupaten Majalengka. Proses triangulasi dalam penelitian ini di lakukan untuk menguji keabsahan data dengan cara di review oleh peneliti lainnya. Mudjia Rahardjo (2012) Triangulasi sumber data adalah menggali kebenaran informai tertentu melalui berbagai metode dan sumber perolehan data. 


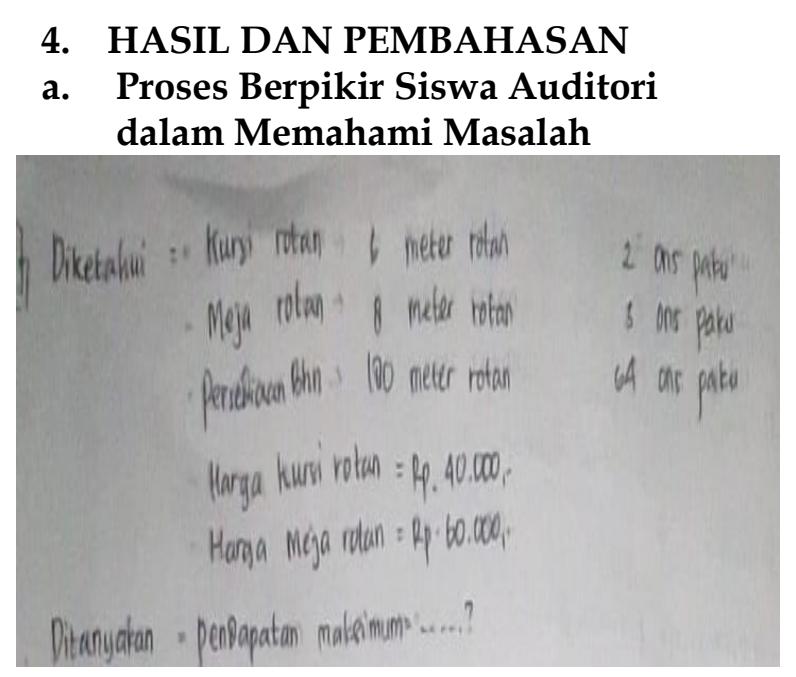

Gambar 1 Pemahaman Soal

Peserta Didik Auditori

S1 menuliskan apa yang diketahui dan apa yang ditanyakan dengan baik pada lembar jawaban. S1 menyatakan apa yang diketahui dari soal dengan bahasanya sendiri. Dari apa yang dituliskan oleh S1, dia memiliki kemampuan proses berpikir konseptual.

Rangkuman percakapan dari wawancara pemahaman ini adalah sebagai berikut:

$\mathrm{P}$ : apa yang diketahui dari soal?

S1 : yang diketahuinya itu banyak rotan dan paku yang diperlukan untuk membuat kursi dan meja, banyak bahan yang ada dan harga dari kursi sama rotan pak.

$\mathrm{P}$ : apa yang ditanyakan dari soal ?

S1 : yang ditanyakan itu nilai maksimum dan pendapatan maksimum.

S1 menyampaikan semua yang ditanyakan dengan lugas dan percaya diri. Dia menggunakan semua informasi yang didapatkannya untuk membentuk pemahaman yang mempermudahnya. Dari jawabanjawaban yang diberikan, dapat disimpulkan bahwa S1 memiliki kemampuan proses berpikir konseptual.

\section{b. Proses Berpikir Siswa Auditori dalam Perencanaan Pemecahan Masalah}

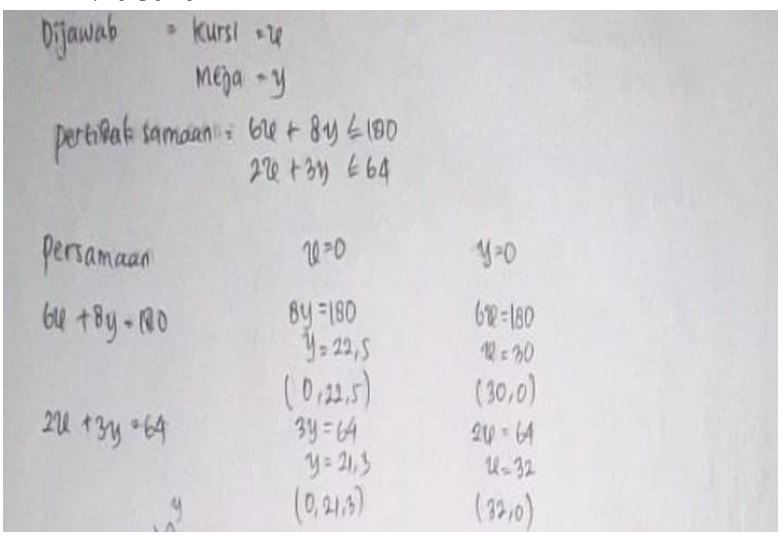

Gambar 2 Perencanaan Peserta

Didik Auditori

Dari apa yang dituliskan oleh S1, dia menuliskan dengan lengkap perencanaan untuk menyelesaikan masalah. Dengan demikian kemampuannya dalam merencanakan memiliki proses berpikir konseptual.

Rangkuman wawancara dari kemampuan perencanaan adalah sebagai berikut:

P : Dijawaban mengapa tidak menggunakan tabel persamaan

S1 : Sebenernya pakai pak tapi tabelnya dihapus biar rapih.

$\mathrm{P}$ : Kenapa garisnya dibuat persamaan dulu?

S1 : untuk menemukan titik $\mathrm{x}$ dan $\mathrm{y}$ pada grafik pak. Terus nantinya dicari titik potongnya.

$\mathrm{P} \quad$ : Terus untuk menemukan DHP bagaimana?

S1 : nanti kalo garisnya udah ada, tinggal diarsir menurut arah kurang atau lebih darinya pak hehe.

Yang dikerjakan S1 dalam mengumpulkan informasi untuk menyelesaikan masalah dengan merencanakannya dengan lengkap. Kemampuan perencanaannya sangat lengkap itu dapat dikatakan proses berpikirnya adalah konseptual. 


\section{c. Proses Berpikir Siswa Auditori dalam Memahami Masalah}

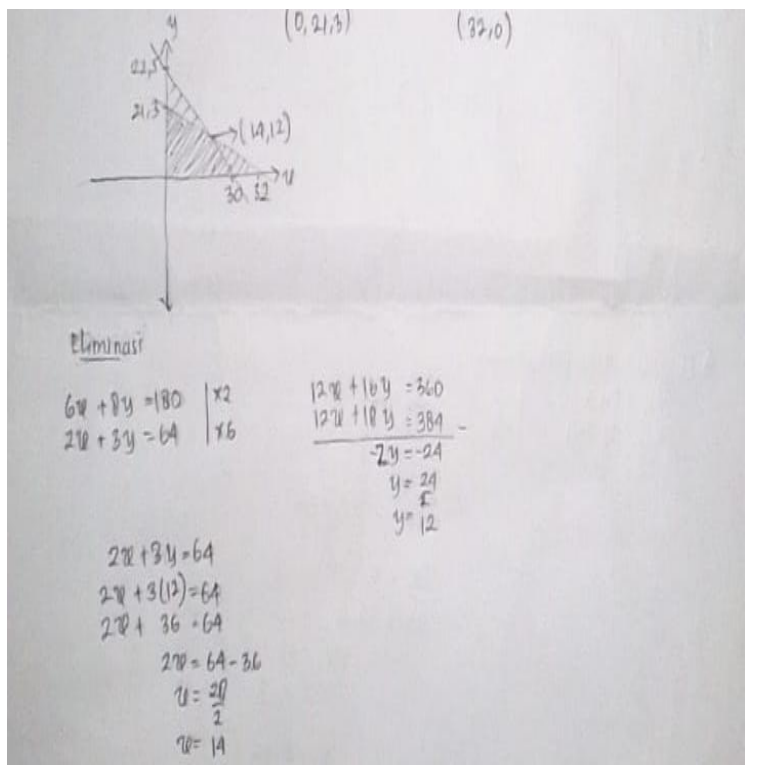

Gambar 4.14 Penyelesaian Soal 2

Peserta Didik Auditori

S1 sangat baik menuliskan langkahlangkah penyelesaian masalahnya. Kemampuan menyelesaikan masalah S1 sangat baik dalam menyelesaikan masalah matematis. Dia memiliki proses berpikir konsepsual dalam menyelesaikan masalah ini.

\section{a. Proses Berpikir Siswa Auditori dalam Memahami Masalah}

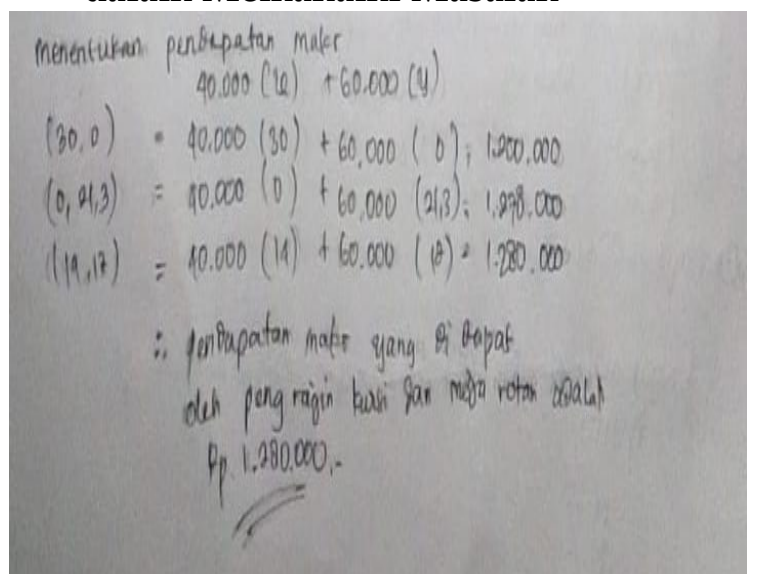

Gambar 4.16 Memeriksa Kembali Soal 2

Peserta Didik Auditori

Rangkuman hasil wawancara dalam mengecek kembali adalah sebagai berikut:

P : Sudah selesai jawab soalnya?
S1 : InsyaAllah sudah beres pak hehe.

P : Coba cek ulang lagi barangkali ada yang tertinggal (Siswa memeriksa kembali jawabannya)

S1 : DHP udah, nilai maksimum udah, pendapatan udah. Udah semua kayanya pak.

Sehingga dapat disimpulkan S1 memiliki kemampun proses berpikir semi konseptual pada kemampuan mengecek kembali jawaban.

\section{KESIMPULAN}

Proses berpikir peserta didik di Kelas XI MIPA MA Siti Khadijah Sindangwangi dengan gaya belajar auditori dalam memecahkan masalah matematis. Dalam langkah memahami masalah, peserta didik dengan gaya belajar auditori memiliki proses berpikir konseptual. Pada langkah merencanakan pemecahan masalah peserta didik ini juga memiliki proses berpikir konseptual. Dalam memecahkan masalah memiliki proses berpikir konseptual. Dengan mengecek kembali jawaban peserta didik ini mampu mengecek apa yang diseharusnya dijawab sehingga dapat dikatakan memiliki kemampuan proses berpikir konseptual. Sehingga dapat disimpulkan peserta didik tersebut memiliki kemampuan pemecahan masalah yang baik. 


\section{REFERENSI}

Carmo, L., Gomes, A., Pereira, F., \& Mendes, A. (2006). Learning styles and problem solving strategies. Paper presented at the Proceedings of 3rd E-Learning ConferenceComputer Science Education (CDROM), [Online] Tersedia: http://elconf06.dei.uc.pt/pdfs/pa per36.pdf

Khodijah, Nyayu, (2014). Psikologi Pendidikan. Jakarta: PT. Raja Grafindo Persada.

Moleong, Lexy J., (2017). Metode Penelitian Kualitatif. Bandung: PT Remaja Rosdakarya.

National Council of Teachers of Mathematics. 2000. Principles and Standards for School Mathematics. Reston: NCTM.

NCERT (2017) Chapter 8 : Thinking, [online] tersedia: ncert.nic.in/ncerts/1/kepy108.pdf

Rahardjo, Mudjia (2017) Studi Kasus Dalam Penelitian Kualitatif: Konsep Dan Prosedurnya. [Online] Tersedi: $\quad$ http://repository.uinmalang.ac.id/1104/1/studi-kasusdalam-penelitian-kualitatif.pdf

Retna, Milda., Mubarokah, Lailatul., dan Suhartatik. (2013). Proses Berpikir Siswa dalam Menyelesaikan Soal Cerita Ditinjau Berdasarkan Kemampuan Matematika (The Student Thinking Process In Solving Math Story Problem). Jurnal Pendidikan Matematika STKIP PGRI Sidoarjo Vol. 1 No. 2. September 2013.

Sugiyono, (2016). Metode Penelitian Kuantitatif, Kualitatif dan R\&D. Bandung: Alfabeta.

Sutarto (2017) “Teori Kognitif dan Implikasinya Dalam Pembelajaran, [Online] Tersedia: https://www.google.com/url?sa=t \&rct $=j \& q=\& e s r c=s \&$ source $=$ web\&c d=2\&ved=2ahUKEwju7LmH6avh AhU54HMBHe5jA8AQFjABegQIB
hAC\&url=http $\% 3 \mathrm{~A} \% 2 \mathrm{~F} \% 2 \mathrm{Fjournal}$ .staincurup.ac.id\%2Findex.php $\% 2 \mathrm{~F}$ JBK\%2Farticle \%2Fdownload \%2F33 1\%2Fpdf\&usg=AOvVaw1qSTWZ4 vM97PSLIApiom5r.

Syah, Muhibbin, (2017) Psikologi Pendidikan dengan Pendekatan Baru. Bandung: PT. Remaja Rosdakarya.

Widyastuti, Rani. (2013). Proses Berpikir Siswa SMP dalam Menyelesaikan Masalah Matematika Ditinjau LangkahLangkah Polya ditinjau Dari Adevrsity Quotient. Program Paska Sarjana Universitas Sebelas Maret. Surakarta.

Zuhri, D. 1998. Proses Berpikir Siswa Kelas II SMPN 16 Pekanbaru dalam Menyelesaikan Soal-Soal Perbandingan Berbalik Nilai.Tesis tidak dipublikasikan. Surabaya: pascasarjana Unesa 